\title{
TEACHING JOB INTERVIEW PROGRAM AT LTE CRUISE PARE KEDIRI
}

\author{
Ahmad Alfan Alfinani
}

\begin{abstract}
Job interview is important to know the characteristic of employees' candidates. Due to this reason, LTE Cruise Ship offered a program about job interviews for cruise ships. This program was collaborated with a cruise ship agency, so, the students could be hired easily after graduation. This study aims to carry out the preparation of teaching of job interview program at LTE Cruise Pare Kediri, the teaching-learning process, the students' response, and the evaluation. This study used a qualitative method. There are some instruments used to collect the data, they are; observation checklist, interview guide, and list of documents. This research reveals some findings related to the focus, they are; (1) the preparation of teaching job interview program at LTE Cruise was supported by syllabus and lesson plan based on the cruise ship agency, (2) the teaching-learning process consisted of 8 meetings for material and simulation, (3) the students give good respond because they feel help with the material to prepare their job interview in a cruise ship, and (4) the evaluation was done twice in the middle and final. Through this result, it was suggested that the manager could make the complete syllabus, the tutor could give warm-up before the material, the students suggest to do individual practice in arranging sentences, the readers to look for another course that over the material of job interview for cruise ship, and for the next researcher was suggested to look for unique courses about cruise ship in different English course.
\end{abstract}

Keywords: Job Interview program, LTE Cruise Pare

\section{INTRODUCTION}

English as an international language is needed in job area. The globalization era forces people to keep in touch with people from the different countries in any businesses such as job field. However, getting s job was not easy because people should pass some steps like job interview. Moreover, getting s job was not easy and the job vacancy cannot be found everyday. Yet, cruise ship agency still needed some professional workers that mastering English.

Since 2012, cruise ship industry have paid more attention to the training and education of cruise professionals, and in practice, they have paid more attention to cooperation and exchanges with international companies and institutions. Both cruise companies and institutions are beginning to realize that talent is fundamental to the development of cruise emerging industries. In line with this case, LTE Cruise has a solution that offer an English course to prepare the students before working in the cruise ship. 
LTE Cruise is the institution that run on training and preparing the candidate of employees for cruise ship. It is the only one cruise ship course in Pare that offer training facility with international standard because it has relation with cruise ship agency. One of the preparation is program about job interview special for cruise ship is LTE Cruise. LTE Cruise has their uniqueness in serving the teaching for cruise and marine. It also does cooperation with some companies of cruise ship, so the students can be hired easily in the cruise ship after graduated.

This research was focused in reveal the preparation of teaching job interview for cruise ship at LTE Cruise Pare, the teaching process of job interview for cruise ship at LTE Cruise Pare, the students' response of teaching job job interview for cruise ship at LTE Cruise Pare, and the evaluation of teaching job interview for cruise ship at LTE Cruise Pare.

\section{METHOD}

The method was used descriptive qualitative study to analyze the data. The data was collected by using some instruments such as (1) observation checklist and field note to collect data through observation, (2) interview guide to collect the data through interview with informants, and (3) list of documents to get the data by analyzing the documents. The data sources in this study was the informants, they are the owner, the tutor, and three of students from job interview for cruise ship program. Those data was analyzed by using theory from Miles and Huberman (1994) as cited in Sugiyono (2014: 247-252) that consist of data reduction, data display, and verification. Then, those data was checked the credibility by using triangulation.

\section{FINDING AND DISCUSSION}

This study revealed about the the preparation of teaching job interview program at LTE Cruise Pare, the teaching process of job interview program at LTE Cruise Pare, the students' response of teaching job interview program at LTE Cruise Pare, and the evaluation of teaching job interview program at LTE Cruise Pare.

The first finding was about the preparation. To know the information about preparation, tutor and the owner was interviewed. In interview, they said that they prepare syllabus and lesson plan before the periode started. Through observation that was done, the owner has gotten syllabus from cruise ship agency. That syllabus had the list of material for job interview program in one periode. It can be concluded that the kind of syllabus is content-based syllabus. Krahnke (1987: 23) said that content based syllabus is used to teach some content or information using the language that the students are also learning. Based on this syllabus, tutor developed into the lesson plan in each unit. Not only from the syllabus, the lesson plan was based on the discussion with the students and what the students' need. It means that the lesson plan in each periode would be different. The cause of this policy is the owner realize that the need of students in each periode was different. The way to teach them also should be different. The developing of the lesson plan was based on theory of Herbart $(1766$ - 1841) about five steps on lesson plan, 
they are: preparation, presentation, association comparison, generalizing, and application.

The second finding was about the teaching and learning process was done in one periode and had done to be observed. The teaching process was opened by greeting the students and pray together. After that, tutor checked the attendance list. In whilst activity, tutor asked some questions of material that day, for example in the first meeting the material was asking students to do introduction. The material in one periode was about introduction and education background, hometown and hobby, family verification, reviewing before middle test, position applied for, knowing the company, ship interest, and reviewing before final test. After knowing their answer, tutor showed the explanation through projector. LCD projector is one of the media by Ministry of National Education (2009:6) from the seven media has been mentioned. Then, the tutor gave general explanation about job interview and the way to answer it, the attitude to answer, and the description of questions will appear on job interview. Then, tutor asked students to read the related material in their handbook. After the session, tutor gave the time for question and answer. Then, he showed the video of related material. After the students understood the material, tutor asked them to do simulation with their friends in pair and vice versa. Simulation and question answer includin in free technique. During this practice, tutor checked the students one by one and gave correction if they do mistake. After the practice, tutor reviewed the material and closing the class.

The third finding was about students' response. During the period, all students which consist of 8 male students were active to follow the class. It can be proved by the attendance list that they never miss the class during the period. They also always on time to attend the class. When the tutor asked the students to do the exercise or simulation, they would do that without complaining. It means that the students are serious and enthusiast to follow the class. Their attitude in following teaching and learning process describing their intention to be hired in cruise ship. Then, from the students' response through interview, can be concluded that the students was helped with this program because through this job interview program they can well prepared and face real job interview. It can be the best experience for them to feel the real job interview. The tutor also gave tips and trick, and also share his experience about job interview, so the students can learn more. The students also feel enthusiast when the tutor gave them feedback and did simulation.

The fourth finding was about the evaluation. Tutor evaluated the students twice in a periode, in the middle at fifth meetings and in the last meeting. The evaluation was started at 07.00 a.m. The tutor opened the class by praying together and checking students' attendance list. Before the evaluation, the tutor gave time to review the material and 15 minutes for students to study by themselves. After the students were ready, the tutor asked students one by one to get interview. For the first, the tutor askes students to introduce themselves. Then, the tutor gave some questions related to the material they had been learnt and the students answered it. The last was the tutor asked students' motivation and goal to be hired in cruise ship. After all of the questions were done, the tutor gave review 
of the students' answer and performance. After all students finished the evaluation, the tutor gave general review. Then, the exam was finished and the class was closed by reciting hamdalah.

\section{CONCLUSION}

There was four conclusions of this research, they were: (1) The syllabus was included to the content based and the lesson plan was developed by tutor from the syllabus and depends on the students' need. (2) Teaching learning process was done through giving material in each week. Those materials were implemented by giving simulation through traditional oR face to face interview. Moreover, in teaching learning was using direct method and free technique named simulation. (3) The students have good respond in teaching and learning process because they need to be hired is passed the job interview. (4) The evaluation was done twice, at middle and final. There were some steps to be done by students in evaluation, they were; introducing themselves, answering interview questions, and gave their motivation and goal to be hired.

Based on this study, it was suggested that for the manager in arranging the syllabus completed with the structure, function, situation, topic, and skills. Then, the tutor should give warming up and develop the variation in learning, so the students would not being bored. For students, they should do more individual practice to arrange the sentence and prepare the answer, so when the questions were coming, they do not need to think the answer or arrange the sentence first. For the readers, it was suggested to look for the course of cruise ship that has relation with agency such as LTE Cruise. For the next researcher, it is suggested to look for unique courses about cruise ship from the material, the method, the technique or the strategy in teaching.

\section{REFERENCES}

Brown, H. D. (1994). Teaching by Principles. NJ: Prentice Hall Regents.

Danasaputra, I. G. 2011. Job Interview in English. Bandung: Ruang Kata imprint Kawan Pustaka.

Hutchinson, T., \& Waters, A. (1987). English for Specific Purposes. Cambridge university press.

Kisamore, J. L., Casper, W. J., Martin, J. A., \& Hall, S. M. (2004). More Tips for Obtaining a Job in Academia. Bowling Green, Ohio, US: APA Division 14, Society for Industrial and Organizational Psychology.

Krahnke, K.J. (1987). Approaches to Syllabus for Foreign Language Teaching. New Jersey: Prentice-Hall Inc.

Larsen-Freeman, D. (2000). Techniques and Principles in Language Teaching. New York: Oxford University.

Nunan, David. 1988. Syllabus Design. New York: Oxford University Press.

Prasetyo, A.W. 2016. TOP NO.1 Tes Masuk Kerja. Jakarta: PT. Bintang Wahyu.

Shicheng, Y. 2012-2013. China Cruise Development Report [M]. Shanghai Pujiang Education Press. 2013: 2.

Sugiyono. (2014). Mettode Penelitian Pendidikan Pendekatan Kuantitatif,. Kualitatif, dan R\&D. Bandung: Alfabeta. 